\title{
Critical Theory and the Prospects of Radical Democracy
}

Paolo A. Bolaños

\begin{abstract}
In this paper I emphasize the link between Honneth's critical theory and radical democracy as defined by C. Douglas Lummis. I, firstly, present Lummis's portrayal of radical democracy, emphasizing the original meaning of the notion of democracy as essentially radical in contrast to muddled conceptions of democracy. I, then, briefly present a characterization of radical democracy as a philosophical and normative principle. I emphasize, following Lummis, that what is radical in democracy is common sense language that collectively binds people. I relate this to Hegel's idea of Sittlichkeit. Gesturing towards the idea that democracy is a kind of participative discourse, I propose that Honneth's theory of social freedom is a third possibility between Habermas's deliberative discourse and Mouffe's agonistic discourse. I, then, rehearse the three normative claims of Horkheimer to contextualize Honneth's commitment to critical theory, allowing me to present a schematic account of his theory of social freedom which is ironically Hegelian inspired, but decidedly critical of Hegel's characterization of democracy. I conclude by relating Benjamin's image of "the tradition of the oppressed" with the notion of social freedom.
\end{abstract}

Keywords: critical theory, radical democracy, social freedom, justice

\section{Muddled Democracy}

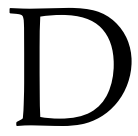
emocracy comes from the Greek words dêmos ("people") and krátos ("power"), literally it means "people power." The Greek idea of dêmos referred to the "poorest and numerous class of citizens." 1 In the Constitution of Athens, Aristotle chronicles how the statesman, Solon, alleviated the crisis of debt that the poor Athenians suffered under the

\footnotetext{
${ }^{1}$ C. Douglas Lummis, Radical Democracy (Ithaca: Cornell University Press, 1996), 15.
} 
wealthy of Athens. ${ }^{2}$ Democracy, therefore, evolved in ancient Greece as a reproach to debt and debt-bondage. As such, dêmos referred to the oppressed class which constituted majority of the Athenian citizenry. In this context, "democracy" or "people power" meant for the Greeks freedom from economic bondage via the empowerment of the most numerous of citizens. This radically anticipates one of the basic tenets of Marxist philosophy, that is, the proletariat's freedom from economic slavery.

From the very beginning, therefore, the idea of democracy presupposes the idea of "the people" and their right to live in a society free from oppression of any ruling class that does not represent the majority. As such, democracy "is a critique of centralized power of every sortcharismatic, bureaucratic, class, military, corporate, party, union, technocractic. By definition it is the antithesis to all such power." ${ }^{3}$ The situation here in the Philippines is quite ironic, however. Democracy, as a theory and practice, is understood based on problematic presuppositions about the idea of "the people."

C. Douglas Lummis, in his book Radical Democracy, points out three instances of misunderstanding the idea of "the people" which will help me illustrate this point. Firstly, there is a misunderstanding of the idea when "the people" is construed to represent the middle and upper classes. This is an instance where democracy is invoked in order to justify the interest of the middle and upper classes, while the lower class - that is to say, the class of servants and laborers - that maintain the surplus of wealth of the former classes is not recognized as a legitimate contributor to the practice of democracy. Secondly, the idea of "the people" is misconstrued as those groups of people who support a particular political party that purports to advocate democratic ideals. Within this framework, the politics of inclusionexclusion is at play - those who adhere to the political party are construed to be advocates of democracy, while those who do not may be seen as "enemies" of democracy, that is to say, "enemies of the people." In such instance, the "enemies of the people" may either meet some level of aggression from

2 Aristotle writes: "it came to pass that the upper classes and the people were divided by party-strife for a long period, for the form of government was in all respects oligarchical; indeed, the poor were in a state of bondage to the rich, both themselves, their wives, and their children, and were called Pelatae (bond-slave for hire), and Hektemori (paying a sixth of the produce as rent); for at this rate of hire they used to work the lands of the rich. Now, the whole of the land was in the hands of a few, and if the cultivators did not pay their rents, they became subject to bondage, both they and their children, and were bound to their creditors on the security of their persons, up to the time of Solon. For he was the first to come forward as the champion of the people. The hardest and bitterest thing then to the majority was that they had no share in the offices of government; not but what they were dissatisfied with everything else, for in nothing, so to say, had they any share." Aristotle, The Constitution of Athens, trans. by Thomas J. Dymes (London: Seeley and Co., Limited, 1891), 1-2.

${ }^{3}$ Lummis, Radical Democracy, 25.

(C) 2020 Paolo A. Bolaños

https://www.kritike.org/journal/issue 27/bolanos december2020.pdf

ISSN 1908-7330

(cc) BY-NC-ND 
members of the political party or they are simply ignored. Thirdly, a variation of the second is when a party or the state presumes that it is the "voice" of the people. However, this often results in the reification of the concept of the people because, instead of actual people governing themselves, representational politics becomes the dominant practice. ${ }^{4}$

The muddled connotations of "the people" mentioned above inform the way Filipinos understand democracy. In the Philippines (probably also elsewhere) the so-called democratic process seems to work for the middle and upper classes. The lower class, albeit constitutes the largest number in terms of voting power, seems to be largely excluded as their votes translate into the election of politicians whose status in society is established by political lineage or by sheer celebrity status. Moreover, the second feature of muddled democracy is also observable in Philippine society. Perhaps the most palpable example is the culture of "bloc voting" by particular groups, especially the religious ones..$^{5}$ Within these religious groups, bloc voting is enacted as a result of the doctrine that no member of the Church should destroy the unity of the Church by voting otherwise than who the Church leaders anoint as their official political candidate. The doctrine is a double-edged sword inasmuch as, on the one hand, the influence of the Church on a government that it helped established is fortified and, on the other hand, bloc voting becomes favorable to politicians aspiring for positions. ${ }^{6}$ There is no room for deliberation and criticism on the part of the Church members, only the vicarious transfer of power, lest one risks expulsion. In terms of the third feature of muddled democracy mentioned above, the political system in the Philippines allows political parties galore. However, despite this mechanism, unnecessarily allowing too many parties is self-defeating. Because every party is saying almost the same thing and advocating almost the same ideals. For instance, what we have is a repetition, through public relations, of the narrative of the plight of the poor, resulting in the reification of the narrative and trivialization of the participatory potential of the people.

At the end of day, politics in the Philippines is endemically patronage-based politics. So, as oppose to a way of life or an ideal, democracy is reduced into a "method" of determining who shall govern. In the Philippines, such method has maintained the culture of political cronyism, patronage, and dynasty.

\footnotetext{
${ }^{4}$ Cf. Ibid., 15-16.

${ }^{5}$ Gerg Cahiles, "Politics of recognition: The power of religious endorsement in the 2019 polls," in CNN Philippines (6 April 2019), <https://cnnphilippines.com/news/2019/4/10/religiousendorsement-philippine-elections.html>.

${ }^{6}$ Fiona Nicolas, "Duterte, Marcos get INC endorsement for May 9 polls," in CNN Philippines (5 May 2016), <https://cnnphilippines.com/news/2016/05/05/Iglesia-ni-Cristoendorsement-duterte-marcos-May-9-elections.html>.
}

(c) 2020 Paolo A. Bolaños https://www.kritike.org/journal/issue 27/bolanos december2020.pdf ISSN 1908-7330 


\section{Radical Democracy as Philosophy and Normative Principle}

The critique of the muddled form of democracy described above would be within the ambit of "radical democracy," a name used by Lummis to describe what he deems as "democracy in its essential form" as opposed to "modified democracies."7 Perhaps, it is important to note here that the notion of radical democracy I am reconstructing is different from a notion of radical democracy based on the idea of sheer "political will" demonstrated by strong leadership. ${ }^{8}$ Following Lummis, I wish instead to illustrate something more fundamental, that is to say, truly "radical" (from the Latin radix which means "root"), to the idea and practice of democracy. Lummis highlights the main features of radical democracy and refers to the idea as a going back to the original meaning of democracy and a veering away from notions of democracy prefixed by modifiers, such as, "liberal," "social," "Christian," etc. It is important to note that the term "radical" is used, not to modify, but to intensify the fundamental feature of democracy - that it is, first and foremost, radical. By radical, Lummis means that democracy has been, from its very inception in ancient Greece, "a critique of centralized power of every sort ... an antithesis to such power." ${ }^{\prime 9}$ Lummis further writes:

... radical democracy is subversive everywhere. It is subversive not only in military dictatorships but also in the countries that are called democratic, those that are called socialist, and those that are "postsocialist." It is subversive not only inside the big corporations but also inside the big unions. It is the idea that joins people struggling for liberty in all countries and all situations if only they could all see in that way. ${ }^{10}$

Apart from a "critical attitude," democracy, says Lummis, is informed by the language of "common sense." This means that democracy, as a way of life and ideal, can be expressed in ordinary language. Lummis, however, points out that ordinary language is more complex than the language of intellectuals, like philosophers and social scientists. "Technical terms are supposed to refer only to specific and clearly defined meanings, whereas the words of ordinary language bear all the complexity of the disorderly history

${ }^{7}$ Lummis, Radical Democracy, 24-25.

${ }^{8}$ See, for instance, Christian Ryan Maboloc, "President Rodrigo Duterte and the Birth of Radical Democracy in the Philippines," in International Journal of Politics and Security, 2:3 (May 2020), 116-134.

${ }^{9}$ Lummis, $\quad \not, 25$.

${ }^{10} \mathrm{Ibid}$.

(c) 2020 Paolo A. Bolaños

https://www.kritike.org/journal/issue 27/bolanos december2020.pdf

ISSN 1908-7330

(c) BY-NC-ND 
of their uses." 11 Common sense is a product of the collective use of ordinary language. Hence, as opposed to a discourse carried out only by intellectual elites in the academe, the discourse of democracy must be carried out in ordinary language. ${ }^{12}$

Structured by common sense language, a language that collectively binds people, democracy, Lummis argues, is a "moral discourse." This entails that democratic discourse is not a random convergence of people, but, rather, it is carried out through moral discourse, choice, and action - it is a result of cooperation, joint action, and agreement, normatively based on a common cause. As such, democracy should not be reduced into a method, but democracy is rather the goal, the ideal. As a goal or ideal, it presupposes the participation of all members of a community. What kind of participation is required by democratic discourse is a question that is yet to be answered; but we can imagine, for a moment, that it could perhaps assume either the deliberative discourse described by Jürgen Habermas or the agonistic discourse described by Chantal Mouffe. For Habermas, democratic discourse is possible through the participation of different parties that accept a given set of rules of action aimed at the realization of a specific end. It is by virtue of this participative agreement that a given set of rules of action is deemed justified. Habermas declares that, "Only those norms can claim to be valid that meet (or could meet) with the approval of all affected in their capacity as participants in a practical discourse."13 Meanwhile, Mouffe takes the notion of democracy a step further by arguing that any type of deliberation rests on a political ontology of agonism she calls "agonistic pluralism." For Mouffe, any identity rests on a relation of difference, that is, the affirmation of the difference of the other (constitutive outside), thereby setting the stage for antagonisms. ${ }^{14}$ In this context, Mouffe understands antagonism or conflict as the very constitutive element of the democratic process and says that antagonism "is inherent in all human society" and "can take many different forms and can emerge in diverse social relations." 15 Inasmuch as antagonism is inherent in all human relations, Mouffe, nevertheless, argues that the "aim of democratic politics is to transform an 'antagonism' into an 'agonism'."16 In

\footnotetext{
11 Ibid., 21

${ }^{12}$ Cf. Ibid.

${ }^{13}$ Jürgen Habermas, Moral Consciousness and Communicative Action, trans. by Christian Lenhardt and Shierry Weber Nicholsen (Cambridge: Polity Press, 1990), 66.

${ }^{14}$ Mouffe writes: "When we accept that every identity is relational and that the condition of existence of every identity is the affirmation of a difference, the determination of an 'other' that is going to play the role of a 'constitutive outside', it is possible to understand how antagonisms arise." Chantal Mouffe, The Return of the Political (London: Verso, 1993), 2.

15 Chantal Mouffe, "Deliberative Democracy or Agonistic Pluralism?," in Social Research, 66:3 (Fall 1999), 754.

${ }^{16}$ Ibid., 755.
}

(c) 2020 Paolo A. Bolaños

https://www.kritike.org/journal/issue 27/bolanos december2020.pdf

ISSN 1908-7330 
this context, the goal of democracy, then, "is not to eliminate passions ... in order to render them rational consensus possible, but to mobilise those passions towards the promotion of democratic designs." 17

If we juxtapose the respective positions of Habermas and Mouffe with that of Lummis, then the importance of language is apparent. Clearly, the Habermasian idea of practical discourse presupposes some sort of common language shared by all participants in a given discourse, the purpose of which is the practical hope of reaching a common understanding of a given situation leading to what he calls "communicative action."18 Meanwhile, despite the fact that Mouffe is veering away from a deliberative discourse grounded in the a common rationality of the Habermasian sort, her agonistic pluralism, nevertheless, still presupposes that identities are constructed or deconstructed through the agonistic (dialectical) interaction among subjects or groups. Agonistic struggles, according to Mouffe (and Ernesto Laclau), are conditioned by forms of articulation that establish "a relation among elements such that their identity is modified ... The differential positions, insofar as they appear articulated within a discourse we will call moments." 19 In this context, the agonistic interaction among moments-articulated as fixed elements-presupposes a relational ontology that decenters the fixed articulation of elements, as such, the agonal discourse demonstrates the impossibility of the total or final closure of an interaction. This is so because the interaction of elements is not grounded in a fixed totality, but, rather, in contingency. I could perhaps cite an example from the history of the Philippines during the past five decades. The declaration of Martial Law by Ferdinand Marcos in 1972 is an instance of an articulation of an element as a reaction to the threats of the Communist Party of the Philippines (CPP) and Mindanao Independence Movement (MIM). Marcos's declaration came not without any "antagonisms" from oppositional figures and the reign of martial rule itself was marred by instances of human rights violations, corruption, and various abuses. These antagonisms exposed the internal limitations of martial rule which finally resulted in the ouster of Marcos during the 1986 People Power event-a moment in the history of the Philippines that "disarticulated" the tyrannical Marcos regime. In recent years, however, it seems like Filipinos have been witnessing a "rearticulation" of martial rule, a climate that creates the opportunity for critique and disarticulation; the suppression of critique is of course to be

\footnotetext{
${ }^{17}$ Ibid., 756.

18 See Jürgen Habermas, The Theory of Communicative Action, Vol. 1, trans. by Thomas McCarthy (Boston: Beacon Press, 1984), 273-337.

${ }_{19}$ Ernesto Laclau and Chantal Mouffe, Hegemony \& Socialist Strategy: Towards a Radical Democratic Politics (London: Verso, 1985), 105.

(c) 2020 Paolo A. Bolaños https://www.kritike.org/journal/issue 27/bolanos december2020.pdf ISSN 1908-7330
}

(c) BY-NC-ND 
expected.20 For Mouffe, this sort of antagonism is a "negation of a given order," one that "is, quite simply, the limit of that order, and not a moment of a broader totality." 21

Given the above, the difference between Habermas and Mouffe is that the former advocates a version of democratic discourse based on a shared rationality, while the former is showing us that our socio-political activities are governed not by the logic of reason, but, rather, by the logic of contrariety. In other words, while Habermas seems to envision the possibility of a final solution to socio-political conflict, Mouffe understands conflict as the very ontological given of socio-political reality. Any political change, therefore, for Mouffe, is conditioned not by agreement, but, rather, by disagreement. Nevertheless, despite their fundamental difference, I believe that both Habermas and Mouffe presuppose that language, in this case discourse, is part of the ontological makeup of socio-political interactions-hence, of democratic discourse. In consideration of these two contrasting positions, it seems to me that Lummis, while pegging radical democracy on common sense language, understands democratic discourse as not simply a methodical process of agreement (ala Habermas), but, rather, it is an aggressive articulation of disagreement with centralized power, as pointed out above. Similar to Mouffe, Lummis understands democracy as a subversive (antagonistic) stance, one that competes (agonistic) with a given oppressive order. Notwithstanding this fundamentally subversive character of democracy, Lummis notes that this subversive performance is a moral discourse since it is normatively informed by a common cause: the realization of freedom.

Since democracy is an ideal, a way of life, and not a method, it is not simply a specific kind of government or economic system (as opposed to the commonly held idea). On the contrary, democracy is the goal that a government or an economic setup should strive to achieve. G. W. F. Hegel is, of course, decidedly an anti-democratic philosopher, but, ironically enough despite his political elitism, the same idea he used in Grundlinien der Philosophie des Rechts (Elements of the Philosophy of Right), Sittlichkeit or the "ethical life" life of a community, could also be used to describe what democracy is. This is precisely what we can observe Axel Honneth is doing in Das Recht der Freiheit (Freedom's Right), a point which I shall elaborate in the next section. Suffice it to say for now that democracy is a historical project that requires the active participation of a community of individuals. To quote Hegel:

\footnotetext{
${ }^{20}$ Cf. Jove Jim S. Aguas, Paolo A. Bolaños, and Jovito V. Cariño, “The Spectre of Terror: Philippine Democracy and the Threat of the New (Ab)normal," in Interfere Blog (28 August 2020), $<$ https://interferejournal.org/2020/08/28/the-spectre-of-terror/>.

${ }^{21}$ Laclau and Mouffe, Hegemony \& Socialist Strategy, 126.
}

(c) 2020 Paolo A. Bolaños https://www.kritike.org/journal/issue 27/bolanos december2020.pdf ISSN 1908-7330 
The right of individuals to their subjective determination to freedom is fulfilled in so far as they belong to ethical actuality; for their certainty of their own freedom has its truth in such objectivity, and it is in the ethical realm that they actually possess their own essence and their inner universality.

Those pedagogical experiments in removing people from the ordinary life of the present and bringing them up in the country (cf. Rousseau's Emile) have been futile, because one cannot successfully isolate people from the laws of the world. Even if young people have to be educated in solitude, no one should imagine that the breath of the spiritual world will not eventually find its way into this solitude and that the power of the world spirit is too weak for it to gain control of such remote regions. The individual attains his right only by becoming the citizen of a good state..$^{22}$

According to Lummis, this participation, that is the integration of an individual into society must be measured against the backdrop of democracy:

... democracy is one of those beautiful, absolute, clear principles ... that poses a maddening, tantalizing puzzle to humankind. It is because there is no sure, fixed solution to this puzzle-the puzzle of how to realize democracy in our collective life-that our commitment to it can take the form only of a historical project. And how successful institutions may be in coming close to it, democracy itself-like justice, equality, and libertyremains as a critical standard against which all institutions may be measured. ${ }^{23}$

As such, we can view democracy as a normative principle inasmuch as it is "a critical standard against which all institutions may be measured." Lummis goes as far as saying that radical democracy "is the foundation of all political discourse" 24 inasmuch as it is concerned about the object of politics which is "power." The normative content of democracy, which is freedom, is the

\footnotetext{
${ }^{22}$ G.W.F. Hegel, Elements of the Philosophy of Right, trans. by H.B. Nisbet (Cambridge: Cambridge University Press, 1991), §153.

${ }^{23}$ Lummis, Radical Democracy., 22-23.

${ }^{24}$ Ibid., 26.

(c) 2020 Paolo A. Bolaños

https://www.kritike.org/journal/issue 27/bolanos december2020.pdf

ISSN 1908-7330
}

(c) $)$ BY-NC-ND 
principle behind the people's call for justice, that is to say, the eradication of injustice. In this sense, then, it appears to me that the agonal discourse that Mouffe has been describing is not incompatible with the notion of radical democracy that Lummis is proposing. However, what Mouffe does not clearly enunciate is the moral import of agonal discourse. One could, nevertheless, assume that, since antagonisms are political reactions to a dominant order (presumably with the tendency to oppress, like, martial rule), Mouffe is actually motivated by her critical outlook on oppressive sociopolitical orders.

\section{Critical Theory and the Idea of Freedom}

I argue that the link between radical democracy and critical theory is the normative character of democratic discourse. Based on Max Horkheimer's Critical Theory essays, we could summarize critical theory as a philosophical and political position via three interrelated claims: (1) critical theory is a discourse that is normatively based on human affairs; (2) critical theory advocates the abolition of slavery and social injustice; and (3) critical theory decentralizes the discourse of emancipation from the proletariat to other social groups. ${ }^{25}$ All three normative claims, I believe, intensify the idea of radical democracy so far described in the foregoing. This is possible if we recast these normative claims within the ambit of radical democracy.

The anthropological shift in critical theory, I argue, brings back democratic discourse to the people who constitute society. I have mentioned earlier that democratic discourse is informed by the ordinary language of the people; hence, normatively, it is a practice that takes shape based on the behavioral patterns of people in a given community.

The second normative claim of critical theory is the strongest, the abolition of slavery and social injustice, and one which resonates very well with the basic normative question of radical democracy: "What is justice?" I take this question to mean, what are we going to do with social injustice?

The third normative claim of critical theory, the decentralization of the emancipative impulse, can also be described as the democratization of emancipation. The early members of the Frankfurt School veered away from Georg Lukacs's over-valorization of the role of the proletariat class in his History and Class Consciousness and they viewed emancipation as a possibility for the greatest number of people or for other social groups. They saw the

${ }^{25}$ Cf. Max Horkheimer, Critical Theory: Selected Essays, trans. by Matthew J. O'Connell, et al. (New York: Continuum, 2002). For a more detailed discussion, see my "The Ethics of Recognition and the Normativity of Social Relations: Some Notes on Axel Honneth's Materialist Philosophical Anthropology," in Suri: The Official Journal of the Philosophical Association of the Philippines, 1:1 (2012), 15-24.

(c) 2020 Paolo A. Bolaños

https://www.kritike.org/journal/issue 27/bolanos december2020.pdf

ISSN 1908-7330

(cc) BY-NC-ND 
over valorization of the proletariat class as another form of social elitism that has the potential to exclude other social groups.

In his debate with Nancy Fraser, Honneth defends his position against the former's accusation that the latter's recognition theory is nothing more than moral psychology and culturalism. This means, for Fraser, that Honneth's recognition theory is not able to practically address sociological and economic issues. Honneth, however, disputes this and argues that recognition theory offers a normative basis for freedom and justice. ${ }^{26}$ Seen in this light, it is perhaps possible to interpret Honneth's theory of theories of recognition and social freedom within the context of radical democracy, that is, a radical democracy informed by the three normative claims of critical theory I pointed out above. As a third option, that is between Habermas's deliberative democracy and Mouffe's agonistic democracy, a theory of social justice may be positioned at the middle inasmuch as it takes deliberative participation as an essential element of democratic discourse, on the one hand, and also seriously takes conflict or disagreement as a normative element of the discourse.

As with Lummis's position that radical democracy is a historical project, Honneth views democratic discourse as a distillation of recognitive struggles. For Honneth, recognitive struggles are the social bases for the possibility of intact recognitive relations. This could be understood in two levels. First, recognitive struggles are the normative bases for the development of a sense of ethical subjectivity within each individual. As such, these struggles develop within individuals a sense of social dignity inasmuch as they become part of the dynamics of the community. Second, recognitive struggles could also be manifestations of the clamor of disrespected individuals or social groups to regain their sense of social integrity. Following Hegel and Mead, Honneth notes, that "individuals must know that they are recognized for their particular abilities and traits in order to be capable of self-realization, they need a form of social esteem that they can only acquire on the basis of collectively shared goals." ${ }^{27}$ As such, a claim can be made that a democratic recognitive process is tenable inasmuch as it aims to regain the social dignity of individuals or social groups. Said another way, the radicality of Honneth's recognition theory can be observed in its attempt to bridge the gap between, on the one hand, the experience of individual autonomy and bodily integrity of individuals, and, on the other hand, how these are made possible through the dynamics of community life.

\footnotetext{
${ }^{26}$ See Axel Honneth, "Redistribution as Recognition: A Response to Nancy Fraser," trans. by Joel Golb and James Ingram, in Redistribution or Recognition? A Political-Philosophical Exchange (London: Verso, 2003), 110-197.

${ }^{27}$ Axel Honneth, The Struggle for Recognition: The Moral Grammar of Social Conflicts, trans. by Joel Anderson (Cambridge, Massachusetts: The MIT Press, 1995), 178.

(c) 2020 Paolo A. Bolaños

https://www.kritike.org/journal/issue 27/bolanos december2020.pdf

ISSN 1908-7330
}

(c) $)$ BY-NC-ND 
Meanwhile, in Freedom's Right, Honneth pursues Hegel's immanent approach of "picking up on values and ideas already institutionalized in society." 28 These institutionalized values, according to Honneth, must have a "moral" motivation that leads to the realization of "justice." Honneth contextualizes justice further by arguing that justice depends on the meaning ascribed to the idea of freedom. Nevertheless, he tries to veer away from a presentation of justice that is "merely formal" or "abstract." 29 Instead, Honneth attempts to provide a theory of justice that is already normatively connected to social reality. By social reality he means the "values and ideas already institutionalized in society." Honneth adds: "the demands of justice turn out to be the essence of the norms that contribute to the most appropriate and comprehensive realization of prevailing values within various different systems of action." 30 In this context, Honneth seems to be claiming that the content of norms (values and ideas instituted in society) is precisely what social justice demands-in other words, as with Lummis, the moral motivation of these norms is the realization of democratic life which is, I argue, nothing else but the realization of social justice. Against the backdrop of Hegel's critical stance against democracy's tendency towards an indefensible liberal individualism in the Elements of the Philosophy of Right, Honneth provides an alternative notion of individual freedom in Freedom's Right-offering not only an extension of Hegel's project but also a radical alternative to the latter's view on democracy.

In order to make the connection between democracy and social justice-and, therefore, the connection between democracy and critical theory - it is important that we have a working understanding of Honneth's idea of justice. In conceptualizing a concretely normative, as opposed to formal, notion of justice, Honneth argues that an idea of justice is only meaningful if understood in the context of freedom because, as an ethical idea, justice entails "the meaning that individual freedom takes on the differentiated spheres of action in accordance with their respective function." 31 This means that justice is demanded every time freedom is invoked and there is a plurality of instances of invocations. In Freedom's Right, Honneth identifies three conceptions of freedom which, for him, are various assumptions of what individual freedom entails: 1) negative freedom, 2) reflexive freedom, and 3) social freedom.

\footnotetext{
${ }^{28}$ Axel Honneth, Freedom's Right: The Social Foundations of Democratic Life, trans. by Joseph Ganahl (Cambridge: Polity Press, 2014), 63.

${ }^{29} \mathrm{Ibid}$.

${ }^{30}$ Ibid., 64.

${ }^{31} \mathrm{Ibid}$.
}

(c) 2020 Paolo A. Bolaños

https://www.kritike.org/journal/issue 27/bolanos december2020.pdf

ISSN 1908-7330 
The first, negative conception of freedom assumes that a legally protected sphere in which subjects can act on their own unreflected preferences is a crucial part of individual freedom ...

... reflexive idea claims that freedom depends on the performance of intellectual acts, which are nevertheless regarded as normal acts performed by every competent subject ...

... social idea of freedom takes account of additional social conditions, linking the realization of freedom to the condition that other, accommodating subjects confirm my own aims. ${ }^{32}$

Honneth's three conceptions of freedom is a recasting of the three spheres of "right" presented by Hegel in the Elements of the Philosophy of Right: (1) abstract right (Recht), (2) morality (Moralität), and (3) ethical life (Sittlichkeit). Abstract right refers to the "inherently individual will of a subject" or "exclusive individuality," 33 pertaining to non-interference as a form of respecting individuals. Honneth recast this as negative freedom, that is, the freedom of subjects to pursue their unreflected interest without external interference. The moral sphere, according to Hegel, is the sphere of selfreflection and human interaction, wherein the subjective will becomes conscious of itself through the consciousness of the existence of other subjective wills. The "moral point of view," Hegel notes, is "the point of view of relationship, obligation, or requirement." 34 For Hegel, the establishment of "subjectivity" requires that the abstract will becomes concrete through an interaction with the objective world. ${ }^{35}$ Meanwhile, for Honneth, the moral sphere is the domain of reflexive freedom, wherein the autonomy of an individual is demonstrated through the performance of "intellectual acts" that requires one's reflective comportment. Both the abstract and moral spheres are eventually superseded by what Hegel calls the sphere of ethical life, wherein subjective will is fully integrated in a community which is objective. Hegel maintains that, "Ethical life is ... the concept of freedom which has become the existing ... world and the nature of self-consciousness." 36 Moreover, the objective community transcends not only the abstract will but also the reflective will of morality, as the reflective will is still will unto others. Through the notion of ethical life, Hegel attempts to ground subjective

${ }^{32}$ Ibid., 65.

${ }^{33} \mathrm{Hegel}$, Elements of the Philosophy of Right, §34.

${ }^{34}$ Ibid., $\$ 108$.

${ }^{35}$ Ibid., $\$ 106$.

${ }^{36}$ Ibid., $§ 142$.

(C) 2020 Paolo A. Bolaños

https://www.kritike.org/journal/issue 27/bolanos december2020.pdf

ISSN 1908-7330

(c) BY-NC-ND 
feelings of freedom in the normative objectivity of "laws and institutions which have being in and for themselves." 37 Hegel expresses this idea alternatively as the "concrete concept of freedom," wherein "we are not one-sidedly within ourselves, but willingly limit ourselves with reference to an other." 38 Honneth provides an inflection of this Hegelian notion of concrete freedom as social freedom, that is, freedom conditioned by one's membership in a community, wherein the experience of freedom presupposes that other free individuals recognize me as a member of the community, thereby recognizing also my peculiarities as an individual will. As a participating member of the community, an individual discovers mutual recognitive relations in various societal institutions, such as, family, economy, and politics. These institutions ensure that concrete freedom is realized, thereby achieving what has been hitherto referred to as justice.

\section{Freedom and Democracy}

An ethical society, for Honneth, performs normative practices that maintain social reproduction. One such practice is "democratic politics." I choose only here to discuss democratic politics as an aspect of the ethical society, first, because of space constraints, but, secondly and more importantly, because it is precisely an aspect of Honneth's work that departs from a basic assumption of Hegel's Elements of the Philosophy of Right, namely, that the ideals of an ethical society are opposed to democracy. ${ }^{39}$ According to Honneth:

We will therefore have to depart from the model presented in Hegel's Philosophy of Right in order to begin the normative construction of this third sphere, which in turn can only be analysed adequately if we understand it as an embodiment of social freedom: the institution of the democratic public or 'public sphere', a social space in which citizens form generally acceptable beliefs through deliberative discussion, beliefs that form the principles to be obeyed by the legislature in accordance with the rule of law. ${ }^{40}$

${ }^{37} \mathrm{Ibid} ., \$ 144$.

${ }^{38} \mathrm{Ibid} .$, §7.

${ }^{39}$ For a more detailed discussion of Hegel's critique of democracy, see W. G. Stratton, "The Problem of Democracy in Hegel's Philosophy of Law," in Archiv für Rechts- und Sozialphilosophie, 74:1 (1988), 33-41. For supplemental discussion, see Karin de Boer, "Democracy Out of Joint? The Financial Crisis in Light of Hegel's Philosophy of Right," in Bulletin of the Hegel Society of Great Britain, 66 (2012), 36-53.

${ }^{40}$ Honneth, Freedom's Right, 254.

(c) 2020 Paolo A. Bolaños

https://www.kritike.org/journal/issue 27/bolanos december2020.pdf

ISSN 1908-7330

(cc) BY-NC-ND 
This is what I meant when I mentioned earlier that Honneth offers not only an extension of Hegel's political project but also a radical alternative to the latter's critique of democracy. Hegel's disapproval of democracy goes as far as leaving no room for public referenda or plebiscites in his ideal conception of the state-in other words, no chance for the less financially fortunate "rabble" 41 to participate in the affairs of the state. Hegel, moreover, is largely opposed to open franchise voting and, instead, proposes that the right to suffrage is restricted only to the members of the nobility and the middle class. ${ }^{42}$ Meanwhile, Honneth distances himself from this Hegelian position and reinstates to the members of society the space for democratic deliberation, the "public sphere." It is important to point out that Honneth does not view democratic deliberation in a purely juridical or proceduralist sense since deliberations of this sort have the tendency to "ignore or downplay the dependence of deliberative decision-making on 'free' conditions in the other constitutive spheres of society," 43 namely, family (personal relationships) and economy (the market). It is in this context that we must understand Honneth's caveat that his theory of justice is normatively grounded in social reality, as opposed to abstract conceptions of justice. This charge of abstractness, I believe, is also aimed at Hegel's tendency in the Elements of the Philosophy of Right to propose a top-down theory of state organization, instead of a bottom-up or grassroots approach. As such, it would not be surprising if Hegel is viewed as a political elitist, a view that, unfortunately, dampens the more nuanced and critical aspects of his theory of freedom. By distancing himself from Hegel, at least on the issue of democracy, Honneth re-envisions a more concrete idea of social freedom that is compatible with the fundamental principle of democratic life-he argues that, "the realization of social freedom in the democratic public sphere depends at the very least on the partial realization of the principles of social freedom in the spheres of personal relationships and the market." 44 This is key in understanding Honneth's theory of democracy: democracy or "deliberative will-formation" is legitimate only when "it learns, in the process of continuous debate over the conditions of social inclusion, the necessity of supporting struggles for social freedom in the two other spheres." 45 In other words, the social freedom that the public sphere promises is only derivative of the two bottom spheres of family and economics. This brings us back to what I mentioned earlier regarding common sense language as constitutive of democratic praxis - as the moral content of such praxis. Given the above

\footnotetext{
${ }^{41}$ Hegel, Elements of the Philosophy of Right, §244.

42 Ibid., $\$ \$ 305-311$.

${ }^{43}$ Cf. Honneth, Freedom's Right, 254.

${ }^{44} \mathrm{Ibid}$.

${ }^{45}$ Ibid., 255.
}

(C) 2020 Paolo A. Bolaños

https://www.kritike.org/journal/issue 27/bolanos december2020.pdf

ISSN 1908-7330

(c) BY-NC-ND 
forage for the meaning of freedom and justice, I can now claim, through Honneth, that common sense language is normatively grounded in the dialectics of our individual right to be free and our intersubjective interactions. I also think that, by emphasizing the normative role of the dialectics of personal relationships and the market-of family and economy - Honneth is revivifying one of the most important insights of Marx regarding the social reproduction of class consciousness, where a group of individuals collectively develop an awareness of their concrete socio-political condition. ${ }^{46}$ By going through this process of self-awareness and selfrealization a group of individuals dialectically develop a sense of individual and group identity (class). Marx usually refers to this process as a "struggle" that is characteristic of a "deeper-lying antagonism" between two social groups, that is, between an oppressor and the oppressed. ${ }^{47} \mathrm{I}$ argue that the dialectical interaction between oppressor and oppressed marks a democratic moment in Marx's theory of class consciousness, as it reflects the radical essence of democratic praxis, namely, a social group's articulation of an antithesis to an oppressive group or system.

\section{Concluding Note: The Dêmos and the Experience of Suffering}

In his 1940 essay, “On the Concept of History,” Walter Benjamin writes:

The tradition of the oppressed teaches us that the "state of emergency" in which we live is not the exception but the rule. We must attain to a conception of history that accords with this insight. Then we will clearly see that it is our task to bring about a real state of emergency, and this will improve our position in the struggle against fascism. One reason fascism has a chance is that, in the name of progress, its opponents treat it as a historical norm. The current amazement that the things we are experiencing are "still" possible in the twentieth century is not philosophical. This amazement is not the beginning of knowledge-unless it is the knowledge

\footnotetext{
${ }^{46}$ Karl Marx discusses his theory of class consciousness in Capital: A Critique of Political Economy, Volume I, trans. by Samuel Moore and Edward Aveling, in Marx E Engels Collected Works (Great Britain: Lawrence \& Wishart, 2010). Georg Lukács offers perhaps the most comprehensive commentary on Marx's theory of class consciousness in History and Class Consciousness: Studies in Marxist Dialectics, trans. by Rodney Livingstone (Cambridge, Massachusetts: The MIT Press, 1971).

${ }^{47}$ Marx, Capital, 146.
}

(c) 2020 Paolo A. Bolaños

https://www.kritike.org/journal/issue 27/bolanos december2020.pdf

ISSN 1908-7330

(cc) BY-NC-ND 
PROSPECTS OF RADICAL DEMOCRACY

\author{
that the view of history which gives rise to it is \\ untenable. ${ }^{48}$
}

Benjamin apparently paints a foreboding image of history. History is not a smooth and linear progression towards the future, but, rather, is marred by the tumultuous dialectics of the past and present. There is a tendency, Benjamin laments, for us moderns to forget about the sufferings of the past in the name of progress; by forgetting the past, the histories and identities of those who suffered are lost. This is the tragedy of the present which Benjamin calls the "state of emergency," a state which we are not yet fully aware of hence, we have lost so much of our histories and of ourselves. Because we continue to forget, we are not only complicit to the crime of fascism, but also continue to suffer. As opposed to a progressive historical materialism, what Benjamin offers as an alternative is a historical materialism from the standpoint of suffering or, in his words, "the tradition of the oppressed." As an image of thought, the tradition of the oppressed provides a historical lens that serves as a constant reminder of past sufferings and warning about the possibility of future sufferings. In this context, we could view this image of thought as a materialist-that is to say, concrete-ethical starting point. I believe that this is what Benjamin means when he says, "We must attain to a conception of history that accords with this insight," so that we "will improve our position in the struggle against fascism." In this sense, if we understand Marx's insight on the self-realization of consciousness, a historical point of view informed by the reality of suffering becomes the ground for the selfrealization of a consciousness that is still suffering. It is suffering because it is still unjustly dominated. The tradition of the oppressed widens our cognitive field and, hopefully, also our vocabulary so that we are going to be better equipped in our struggle against any form of fascism. It is also in this context that we are able to understand what Honneth reminds us about social freedom, that it is not achievable in the consciousness of those who oppress, but, rather, in the consciousness of those who are oppressed.

In my attempt to bring together normative elements from critical theory and the promise of radical democracy, I used, as a point of departure, a working definition of radical democracy offered by Lummis. I am convinced that Lummis offers a powerful description of the radicality of democratic praxis, inasmuch as he emphasizes that the essence of such praxis is precisely the articulation of an antithesis to centralized power. I tried to elaborate on the praxis or articulation of democratic discourse by pointing out three models: (1) Habermas's deliberative discourse, (2) Mouffe's

\footnotetext{
48 Walter Benjamin, "On the Concept of History," in Walter Benjamin: Selected Writings, Volume 4, 1938-1940 (Cambridge, Massachusetts: Harvard University Pres, 2003), 392.

(c) 2020 Paolo A. Bolaños

https://www.kritike.org/journal/issue 27/bolanos december2020.pdf

ISSN 1908-7330
}

(c) $)$ BY-NC-ND 
agonistic discourse, and (3) Honneth's dialectics of social freedom. While I find in Honneth, who represents the contemporary strain of critical theory, a possible rapprochement between the deliberative and agonistic discourses, I think that Honneth's model is the one that is most committed to the normative claims of critical theory, especially the claim on the abolition of slavery and social injustice. Inspired by Hegel's idea of Sittlichkeit, Honneth advances a theory of justice that is grounded in a concrete notion of social freedom which is, at the same time, decidedly anti-Hegelian since Honneth understands the dynamics of social freedom as essentially democratic. As a normative practice, democratic politics provides an agonal space both for self-realization and societal inclusion. The radicality of Honneth's theory of democracy is found in his inflection of Marx's description of the dialectical self-realization of consciousness in the face of conflict. We can relate the Benjaminian image of the tradition of the oppressed with Honneth's commitment to a critical theory grounded in the normativity of the experience of social injustice or suffering. Whose suffering is it that becomes the normative ground for democratic praxis? I believe it is the suffering of the dêmos.

Department of Philosophy, University of Santo Tomas, Philippines

\section{References}

Aguas, Jove Jim S., Paolo A. Bolaños, and Jovito V. Cariño, "The Spectre of Terror: Philippine Democracy and the Threat of the New (Ab)normal," in Interfere Blog (28 August 2020), $<$ https://interferejournal.org/2020/08/28/the-spectre-of-terror/>.

Aristotle, The Constitution of Athens, trans. by Thomas J. Dymes (London: Seeley and Co., Limited, 1891).

Benjamin, Walter, "On the Concept of History," in Walter Benjamin: Selected Writings, Volume 4, 1938-1940 (Cambridge, Massachusetts: Harvard University Pres, 2003).

de Boer, Karin, "Democracy Out of Joint? The Financial Crisis in Light of Hegel's Philosophy of Right," in Bulletin of the Hegel Society of Great Britain, 66 (2012).

Bolaños, Paolo A., "The Ethics of Recognition and the Normativity of Social Relations: Some Notes on Axel Honneth's Materialist Philosophical Anthropology," in Suri: The Official Journal of the Philosophical Association of the Philippines, 1:1 (2012).

Cahiles, Gerg, "Politics of recognition: The power of religious endorsement in the 2019 polls," in CNN Philippines (6 April 2019), $<$ https://cnnphilippines.com/news/2019/4/10/religious-endorsementphilippine-elections.html>.

(c) 2020 Paolo A. Bolaños

https://www.kritike.org/journal/issue 27/bolanos december2020.pdf

ISSN 1908-7330

(cc) BY-NC-ND 
Habermas, Jürgen, Moral Consciousness and Communicative Action, trans. by Christian Lenhardt and Shierry Weber Nicholsen (Cambridge: Polity Press, 1990). The Theory of Communicative Action, Vol. 1, trans. by Thomas McCarthy (Boston: Beacon Press, 1984).

Hegel, G.W.F., Elements of the Philosophy of Right, trans. by H.B. Nisbet (Cambridge: Cambridge University Press, 1991).

Honneth, Axel, Freedom's Right: The Social Foundations of Democratic Life, trans. by Joseph Ganahl (Cambridge: Polity Press, 2014).

"Redistribution as Recognition: A Response to Nancy Fraser," trans. by Joel Golb and James Ingram, in Redistribution or Recognition? A Political-Philosophical Exchange (London: Verso, 2003).

The Struggle for Recognition: The Moral Grammar of Social Conflicts, trans. by Joel Anderson (Cambridge, Massachusetts: The MIT Press, 1995).

Horkheimer, Max, Critical Theory: Selected Essays, trans. by Matthew J. O'Connell, et al. (New York: Continuum, 2002).

Laclau, Ernesto and Chantal Mouffe, Hegemony \& Socialist Strategy: Towards a Radical Democratic Politics (London: Verso, 1985).

Lukács, Georg, History and Class Consciousness: Studies in Marxist Dialectics, trans. by Rodney Livingstone (Cambridge, Massachusetts: The MIT Press, 1971).

Lummis, C. Douglas, Radical Democracy (Ithaca: Cornell University Press, 1996).

Maboloc, Christian Ryan, "President Rodrigo Duterte and the Birth of Radical Democracy in the Philippines," in International Journal of Politics and Security, 2:3 (May 2020).

Marx, Karl, Capital: A Critique of Political Economy, Volume I, trans. by Samuel Moore and Edward Aveling, in Marx \& Engels Collected Works (Great Britain: Lawrence \& Wishart, 2010).

Mouffe, Chantal, "Deliberative Democracy or Agonistic Pluralism?," in Social Research, 66:3 (Fall 1999). The Return of the Political (London: Verso, 1993).

Nicolas, Fiona, "Duterte, Marcos get INC endorsement for May 9 polls," in CNN Philippines (5 May 2016), $<$ https://cnnphilippines.com/news/2016/05/05/Iglesia-ni-Cristoendorsement-duterte-marcos-May-9-elections.html>.

Stratton, W. G., "The Problem of Democracy in Hegel's Philosophy of Law," in Archiv für Rechts- und Sozialphilosophie, 74:1 (1988). 